\title{
Pragmatic Diagnosis and Resolution of Learners' Language Difficulties
}

\author{
Esther Olayinka Bamigbola \\ Department of English Studies, Adekunle Ajasin University \\ P. M. B. 1, Akungba-Akoko, Ondo State, Nigeria \\ Tel: 234-803-603-5457_E-mail: bamigbolayinka@yahoo.com
}

Received: November 11, 2014 Accepted: February 18, 2015 Published: February 24, 2015

doi:10.5296/ijele.v3i1.7155 URL: http://dx.doi.org/10.5296/ijele.v3i1.7155

\begin{abstract}
The school environment is typically a complex social one in which the learner participates. Observing the child in this environment is ideal and should be a priority for diagnosing learner's language competence. This paper examines techniques through which teachers can diagnose learners' language problems. These involve the use of pragmatic tools such as intention, inference and world knowledge. The study also employs the use of the six levels of competence as mapped out by Lawal in his pragma-communicative model to suggest suitable language activities for learners. The activities are just samples to guide language teachers in planning their language lessons. The result of the study reveals that many Nigerian students and generally, second language learners of English, are deficient in demonstrating good and appropriate language behaviours. On the basis of the findings, we recommend a more pragmatic way of teaching English or any other language, as a second language. Also, the number of learners in the classrooms should be reduced to enable the practice of skill-oriented teaching techniques.
\end{abstract}

Keywords: Second language learning, Language problem diagnosis, Pragmatic tool, Pragma-communicative model 


\section{Introduction}

A common problem among Nigerian students in the secondary schools and even post secondary school levels is their inability to demonstrate adequate mastery of the various competence skills associated with the use of English language. Lawal (1995) proposed a 'pragma-communicative model' for interpreting the meaning of lexical items and utterances, observing that the type of meaning a user of English is able to encode or decode will depend on factors such as:

his communicative competence (including both his linguistic and situational competences) his knowledge of the world (including his world-view and socio-cultural background) and his psychological state including his mind and attitude towards the topic, the communicative context and his co-participants in the communicative event. (Lawal 1995:158)

The inability of Nigerian students to interpret lexical items and utterances correctly can be directly linked to lack of adequate competence skills.

Johnson and Brindley (1988) point out that utilizing a skill-oriented approach that places students in authentic situations to practically use language, make mistake, repair them and, most importantly, learn to function in the target language is an ideal method. The reality is that many teachers in Nigeria are often faced with large class sizes, so accomplishing classroom activities proposed by skill-oriented theorists is not an easy task. This does not, however, have to result in a complete disregard of techniques for promoting skill-oriented approach to language teaching. One way of accomplishing this is to create a discussion forum on topics that will interest students. Such a method will definitely enhance and enrich the learning process as well as improve the language competence of learners. Under this learning situation the teacher will be able to observe the learners' individual language difficulties and know how to help them overcome the challenges.

This pragmatic approach will involve the use of the following assessment methods:

- $\quad$ Observing the learner with his peers and in different environments.

- $\quad$ The observer relating with each learner without influencing his performance.

- $\quad$ Asking learners questions on contextual interpretation of words.

This study highlights different techniques through which teachers can diagnose learner's language problems. It also suggests suitable activities that can be used to inculcate the necessary language skills in the learners. The study therefore seeks to answer the following questions:

1. How related are the language competencies proposed by Lawal (1995) to interpretation of utterances?

2. Can these competencies be taught or acquired?

3. What activities suit the teaching of each skill? 


\section{Theoretical Background}

Pragmatics is a layer of linguistics that deals with language in use. It has to do basically with meaning of utterances in context. According to Trauggott and Pratt (1980:226), pragmatics deals with speakers' communicative competence, the knowledge which enables them to produce and understand utterances in relation to specific speech context. When people are engaged in conversations they intuitively look for contextual sense (i.e. the sense in which the speaker/writer uses a word). Jenny Thomas (1995) in "Meaning in Interaction" gives an illustration of how a listener used the knowledge of the context to interpret the word 'lump' read from a newspaper.

According to Aliyu (2006), 'language learning involves the cultivation of specific skills which in the end combine to promote the attainment of general fluency.' He also suggests in an earlier paper entitled "Mass Failure in WAEC-conducted Senior Secondary English Examination in Nigeria: Grammar as Road Block to Candidates' Success", that selected items for examining students in English language should reflect on communicative language use balanced with some recognition for the rules of the language.

Bachman's theoretical framework of communicative language ability (CLA) consists both knowledge competence and capacity for implementing or executing that competence in appropriate contextualized communicative language use. Pragmatic theory is concerned with the mental structure underlying the ability to interpret utterances in context (Blakemore, 1992:18). According to Levinson (1980), the main issue which any pragmatic theory must explain is speech acts, along with presuppositions and implicatures. The theory must also attempt a description of the background competencies, which language users reactivate, to interpret speech acts. It is only then that such theory can serve the necessary diagnostic developmental and remedial purposes in the sphere of language and literary education. Adegbija (1982) states that at every stage of discourse, both speaker(s) and hearer(s) have to mobilise appropriate areas of the pragmatic, social, syntactic, semantic and lexical competencies in order to be able to participate effectively in the interaction at hand.

Pragmatics has to do with the how and the consequences of utterances (Lawal, 1997). If educators remain aware of the impact of using skill-oriented methods and constantly seek out practical language situations on topics which students value, foreign language competence levels based on a communicative approach will be enriched. The demonstration of adequate language skills in different social contexts is a fundamental deficiency in most Nigerian learners. Thus, this research intends to diagnose some of the problems learners of English as second language in Nigeria have, which pragmatics as a field can appropriately tackle. As Peirce (1995) noted, language classrooms provide an ideal arena for exploring the relationship between learners' subjectivity and L2 use.

\section{Test Design and Administration}

Tests and observations were used to obtain information germane to students' competence in required English language skills. The survey population for this study consisted of forty-five (45) SS2 students of Government Day Secondary School, Gaa-Akanbi, Ilorin, Kwara State in 
Nigeria. The selected school is co-educational. Ilorin is an urban settlement in one of the 36 states in the country. The SS2 class is in the upper Secondary level of education and a preparatory class for the final examination for entrance into tertiary institutions. The students in the selected school are mostly learners from enlightened homes and their performance can be taken as a good representation of the students in the larger society. There are three arms in the SS2 class, comprising of science, arts and commercial. The students who participated in the survey were randomly selected from the art class. This is because English - English language and literature - are core subjects in the art class. The assessment itself is multifaceted, pooling information from a variety of sources and contexts. The following activities were carried out in the course of gathering information.

\subsection{Observing the Student Among Peers}

The observation involved the researcher monitoring a student engaged in discussion over a block of time lasting at least 15 minutes on the topic "What I love most." During this time, the researcher observes not only how the student initiates discussions but also how he sustains them and uses appropriate words throughout the period of observation.

\subsection{Interacting With the Students}

For a period of about 5 minutes, the researcher interviewed each student on what he does everyday after school hours. During the interaction, the researcher notes the student's ability to respond appropriately to questions. For example, the researcher says:

"You are Kola Adebayo, an SS2 student of this school. Can you tell me briefly some of the things you do after school everyday?

\subsection{Answering Questions On Contextual Interpretation of Words}

Later, the students were given the following questions to answer:

INSTRUCTION: Explain the meaning of the underlined words in the following statements.

(1) As an old bat was commonly sighted in the village at night, it was common to hear a lot of stories about flying animals.

(2) Sarah requested her guardian to get the correct bust measurement before sewing her school uniform.

(3) In the last promotion exam, Ronke took the lead.

(4) The construction company makes use of lead for their production.

(5) My dad gave her a lovely silver bracelet, one of those chased ones

(6) Ojo couldn't imagine how one bracelet could be more chaste than another, but he didn't ask.

(7) The students were called by the principal to account for their past behaviours.

(8) The boy could not bear the pain. 
(9) The driver denied the accusation.

(10) His father denied him because of his bad behaviour.

The students were allowed the use of their dictionary since many of them may not know the meaning of some words. However, they were informed that out of the multiple meanings a word may have, only one can be correct and should be chosen as appropriate for the context of each statement.

\section{Analysis and Results}

The observations were geared towards assessing the language behaviours of the students. While gathering information about each student's language competence, the researcher observed the following:

The ability of the students to

(1) assign the correct or intended sense to polysemous or homonymous lexical items (words that have more than one possible meaning)

(2) assign correct sense to homographs (words that have the same spelling but different pronunciations and meaning).

(3) assign correct sense to homophones (i.e. words which have the same pronunciation, but different spellings and meaning).

During the observation, the researcher does virtually nothing to influence the students' success in initiating or maintaining discussion.

The responses were graded using the following rating:

$$
\begin{array}{ll}
\text { Excellent } & =80-100 \% \\
\text { Good } & =60-79 \% \\
\text { Fair } & =40-59 \% \\
\text { Poor } & =0-39 \%
\end{array}
$$

Table 1. Rating of Students' Language Behaviours among Peers

\begin{tabular}{|l|l|l|l|l|l|}
\hline \multicolumn{2}{|l|}{$\begin{array}{l}\text { Effectiveness in } \\
\text { Discussing Topic }\end{array}$} & \multicolumn{2}{l|}{$\begin{array}{l}\text { Appropriateness of } \\
\text { Words Used }\end{array}$} & \multicolumn{2}{l|}{ Vocabulary } \\
\hline Rating & Frequency & Rating & Frequency & Rating & $\begin{array}{l}\text { Frequenc } \\
y\end{array}$ \\
\hline $\begin{array}{l}\text { Poor } \\
\text { Fair } \\
\text { Good }\end{array}$ & 15 & $\begin{array}{l}\text { Poor } \\
\text { Fair } \\
\text { Good }\end{array}$ & $\begin{array}{l}15 \\
\text { Extremely }\end{array}$ & $\begin{array}{l}\text { limited } \\
\text { lim }\end{array}$ & 3 \\
\hline
\end{tabular}




\begin{tabular}{|l|l|l|l|l|l|}
\hline & 12 & & 9 & $\begin{array}{l}\text { Small } \\
\text { Moderate }\end{array}$ & 18 \\
\hline
\end{tabular}

Table 2. Rating of Students' Responses During the Interview

\begin{tabular}{|l|l|l|}
\hline $\begin{array}{l}\text { Rating of } \\
\text { Responses }\end{array}$ & Language Behaviours Observed & Frequency \\
\hline Poor & Difficulty in responding because of vocabulary limitation & 15 \\
Fair & Frequently misses or searches for words & 15 \\
Good & Responded appropriately & 15 \\
\hline
\end{tabular}

From the results in Table 1, out of the 45 students observed, nobody has been rated excellent for effectiveness in discussing topics. Only 12 were rated as good, 18 of them were rated as fair while the remaining 15 were rated poor in discussing the topics. This is an indication that majority of the students are lacking in listening and speaking skills. The functional skills that are related to this according to Aliyu (2001:1) include the skills of turn-taking, summarising, spontaneous delivery and time management. It can be concluded therefore that majority of the students are lacking in these skills. Similar responses were elicited to the other parameters in the table.

Table 3. Frequency Counts and Percentages of Students' Answers to Questions on Contextual Interpretation of Words

\begin{tabular}{|c|c|c|c|c|}
\hline Question & $\begin{array}{lr}\begin{array}{l}\text { Number } \\
\text { students }\end{array} & \text { who } \\
\text { Correctly } & \\
\text { interpreted } & \text { the } \\
\text { question } & \end{array}$ & $\begin{array}{lr}\begin{array}{l}\text { Number } \\
\text { students }\end{array} & \text { who } \\
\text { wrongly } & \\
\text { interpreted } & \text { the } \\
\text { question } & \end{array}$ & $\begin{array}{l}\text { Percentage } \\
\text { of Students } \\
\text { who } \\
\text { interpreted } \\
\text { correctly }\end{array}$ & $\begin{array}{l}\text { Percentage } \\
\text { of Students } \\
\text { who } \\
\text { interpreted } \\
\text { wrongly }\end{array}$ \\
\hline 1 & 18 & 27 & $40 \%$ & $60 \%$ \\
\hline 2 & 21 & 24 & $47 \%$ & $53 \%$ \\
\hline 3 & 27 & 18 & $60 \%$ & $40 \%$ \\
\hline 4 & 12 & 33 & $27 \%$ & 73 \\
\hline 5 & 18 & 27 & $40 \%$ & $60 \%$ \\
\hline
\end{tabular}




\begin{tabular}{|l|l|l|l|l|}
\hline 6 & 15 & 30 & $33.3 \%$ & $66.7 \%$ \\
7 & 30 & 15 & $66.7 \%$ & $33.3 \%$ \\
8 & 30 & 15 & $66.7 \%$ & $33.3 \%$ \\
9 & 24 & 21 & $53 \%$ & $47 \%$ \\
10 & 27 & 18 & $60 \%$ & $40 \%$ \\
\hline Average & $\approx 21$ & $\approx 24$ & $\approx 47 \%$ & $\approx 53 \%$ \\
\hline
\end{tabular}

From the result presented in Table 2, only fifteen of the forty-five students were rated good in their responses to the researcher's interview; fifteen performed fairly good but frequently miss and search for words while fifteen had difficulty responding to the interviewer's enquiries as a result of their limitation in vocabulary.

From the data in Table 3, only eighteen of the 45 students, which constitute $40 \%$, gave appropriate interpretation to the word underlined in question 1 while 27 , who constitute $60 \%$ interpreted the word wrongly. Twenty-one (21), making $47 \%$ of the 45 students, interpreted the word in question 2 correctly while 24 (53\%) wrongly interpreted the word. Twenty-seven, making $60 \%$ of the 45 students, interpreted the underlined word in question 3 correctly while $18(40 \%)$ wrongly interpreted it. Only twelve of the 45 students, making $27 \%$, interpreted the word in question 4 correctly while 33, making 73\%, interpreted it wrongly. Eighteen, making $40 \%$ of the students, gave the correct interpretation to the word underlined in question 5 while 27 , which constitute $60 \%$, wrongly interpreted it. Only fifteen, making $33.3 \%$ of the whole, interpreted the word in question 6 correctly while 30, constituting $66.7 \%$, gave a wrong interpretation to it. Thirty, making $66.7 \%$ of the 45 students, interpreted the word in question 7 and 8 correctly while 15, making 33.3\% gave it a wrong interpretation. Twenty-four of the 45 students, making 53\% gave the appropriate interpretation to the word in question 9 while 21, constituting 47\%, gave it a wrong interpretation. For question 10 , twenty-seven of the students, constituting $60 \%$, interpreted the word correctly while 18 , making $40 \%$, gave it a wrong interpretation. On the average, 21 students, representing $47 \%$, gave correct interpretations to the questions while 24 , representing $53 \%$, wrongly interpreted the questions.

It is obvious from the above results that many of the students are lacking in giving correct contextual interpretation to words. This has to do with their inability to assign correct or intended meaning to certain words in statements; inability to draw inferences from statements and in most cases inability to establish point of correspondence between theirs and speakers' or writers' world knowledge. The above results were obtainable having allowed them to make use of their dictionary. This is to make the test more pragmatic, limiting it to only contextual interpretation. 


\section{Recommendations}

From the above observations, the following activities are recommended for the development of various competence skills required to improve the language abilities of learners.

\subsection{Developing Learners' Linguistic Competence}

The language user's linguistic competence has to do with the mastery of lexical, phonological, morpho-syntactic and micro-semantic knowledge of the language. This is referred to as the most fundamental and involves the learner having the basis knowledge of all that relate to the form of the language. This will involve teaching the learner the sound system and pronunciation, the intonation and stress pattern, vocabulary development and the grammar of the language. Below are sample activities that may be employed for the development of the linguistic competence of the learner.

\section{Activity 1}

Below is a list of words which may be spelt differently but have the same or similar pronunciation. Learners should be guided by the teacher to produce the words orally.

\begin{tabular}{|l|l|l|}
\hline A. wither & B. weather & C. whither \\
D. welder & E. whether & F. welter \\
\hline
\end{tabular}

Learners should further be instructed to read the sentences below carefully and from the box above, complete each blanks with the most suitable word.

1. When the travellers took to the road, the was difficult to describe.

2. The Newspaper editorial was simply captioned, “ Nigeria?"

3. The persistent lack of rain may cause the crops to

4. After the lesson the student did not know to complain about the tutor's speed.

5. The landlords who patronized the had a lot to complain about.

\subsection{Test of Orals (Using Cues)}

From the words lettered A to D, identify the word that has the same vowel sound as the one represented by the letter(s) underlined. Underline the correct options.

1. Could (Stressed) 2. Worm
A. fold
A. warm
B. sound
B. corn 

C. drown
C. fern
D. put
D. frown

3. Part
A. cat
B. bark
C. blurb
D. heard

5. Mouse
A. pun
B. horn
C. darn
D. rouse
A. cure
B. near
C. pear
D. queer

4. Core

B. purse

C. ball

D. queer

6. Bear

From the words lettered A to D, identify the word that has the same consonant sound(s) as the one represented by the letter(s) underlined. Underline the correct option.

7. Spray
A. splash
B. span
C. spring
D. strut

9. Thank
A. thames
B. taught
C. thought
D. than

8. Privilege
A. ledger
B. gloom
C. bug
D. burglar

10. Treasure

\subsection{Vocabulary Development}

Complete the given statements by choosing the correct word from the list given in the box.

\begin{tabular}{|ll|}
\hline Coach & plumber pilot \\
matron & pensioner \\
& \\
\hline
\end{tabular}


1. is one who trains players or learners.

2. A ........... is one who mends pipes and other fittings in a house.

3. One who operates the controls of an aircraft or ship is a ...................

4. A............ looks after a hospital ward or a female hostel.

5. One who lives on pension is a

\subsection{Gaining Control of the Grammar of English language}

This is a very wide area and involves the mastery of the English sentence and the various parts of speech. The teacher must try as much as possible to lay a very solid foundation in the learners and give them interesting topics to discuss in order to develop their competence.

Below are sample questions that may be given to students:

Instruction: In each of the following sentences there is a gap. From the options lettered A-E, choose the word or group of words that best completes each sentence.

1. Every member of the family wondered why the relation did not leave a will behind.
A. diseased
B. decease
C. deceased
D. diseases E. disease

2. Only recently did the College stop.... ..books to new students without identity card.
A. lending B. to lend
C. to borrow
D. borrowing
E. to lending

3. "You wouldn't mind coming along with us,
A. would you?
B. won't you?
C. can you?
D. could you?
E. can't?

4. An announcement was made that if anybody had lost an handkerchief..... should see the receptionist immediately.
A. we B. you
C. me
D. I
E. they

5. To everybody's surprise, the woman and her children to be detained.
A. having being ordered
B. have been ordered
C. have being ordered
D. has been ordered 
E. has being ordered

Some common games and activities can also be used for vocabulary development of the learners. Such games include the scrabble, word card, the cross word puzzle and word completion game.

\subsection{Developing Learners'Psychological Competence}

This level of competence has to do with the learner's awareness of and sensitivity to moods, attitudes and points of view. This competence level of the learners can be developed by giving them a passage to read and answer questions such as:

What does the expression "Instrument of Thy light and peace" tell us about the speaker?

\subsection{Developing Learners'Situational Competence}

This competence level has to do with the knowledge of and familiarity with the topic of discourse, the location, objects and persons in the physical setting (Lawal, 1995). This can best be developed through the use of reading activities. The teacher can give questions which require the learners to read through and identify a point or points stated outwardly or directly by the writer. For instance, students could be instructed to read the passage below and answer the questions that follow.

\section{FR. DAMAN IS VICE RECTOR}

Rev Father James Naaman Daman of the order of St. Augustine (OSA) has been appointed the new vice rector of St. Augustine's Major Seminary, Jos. This was made known after the Board of Governors meeting in Jos and was communicated to the students by the rector of the college, Father Michael Apochi, February 2, 1996.

Father James Daman was born in 1956 in Mikel, Quan Pan L. G. A. of Plateau State. He was ordained by Pope John Paul II on his visit to Nigeria in 1982 in Kaduna. He obtained a diploma in Religious Studies from the University of Ibadan and a Bachelor's degree in Sacred Theology. Fr. Daman also holds a doctorate degree in Moral Theology. (Aliyu, 2006:49)

\section{Questions:}

1. What order does Fr. James Daman belong to?

2. To what new position has Fr. Daman been appointed?

3. When was Fr. James Daman born?

4. Who ordained Fr. James Daman?

5. Which university is Fr. James Daman an alumnus of?

Other activities that are suitable for the development of the learners' situational competence include summary writing and storytelling. 


\subsection{Developing Learners'Social Competence}

This has to do with the language user's knowledge of social factors and principles governing conservation. The type of language activities that could help develop the learner's ability in this area include giving him/her passages or story books to read and answer such questions as

(1) Who is the writer of this passage?

(2) What social imbalances does the writer enumerate as the hall-marks of the black Americans' suffering in the novel?

\subsection{Developing Learners' Sociological Competence}

The sociological competence has to do with the language user's knowledge of the socio-cultural and historical background to the utterances. This is the skill that enables the learner to make bold predictions that are based on evidence which may be given or perceived in a text or utterance.

In some situations, a writer/speaker and his audience may be operating within some shared background. Under such circumstances, as Aliyu (2006) rightly said, certain facts or points may be taken as given, that is, regarded as familiar to both writer and reader. The author may, therefore, take the common background knowledge as the premise of starting point for his discussion. The text may contain certain points that are full of hints related to some issues overtly stated. The text may even have some veiled bias. The reader in such cases has to employ several language and socio-cultural tools to make the correct inference.

After reading the following text:

\section{THE US EMBASSY INCIDENT}

Sir: The news story "Nigerian Family Assaulted at US Embassy", The Guardian August 6, 1994 gave a misleading description of an incident that occurred in the American Embassy, Lagos on Friday morning (August, 5). Your story is heavily weighted from the point of view of the Nigerian family and I would like to put some balance to the story.

The Nigerian parents waiting to consular services at our Embassy were not properly supervising their children. One of the children entered the open door to a secured off limits area. When one of our Nigerian employees - not an official as reported - prevented the child from entering the secured area, the father entered, assaulted this employee, and accused him of pushing the child.

One of our American consular officers came to the aid of our employee, and in an attempt to break up the scuffle was herself assaulted by both the man and the woman. Our guards pulled the couple off our Nigerian employee and the American diplomat, and then escorted the couple and their children out of the Embassy.

The incident was not a consular matter, this was purely a security issue. We strive to maintain a safe environment in our Embassy not only for our employees, but also for our clients, whatever services they may require. (US Embassy Official) 
The learner could be asked:

(a) What, from your reading of line 2 in paragraph 2, did the Nigerian parents' action amount to?

\subsection{Developing Learners' Cosmological Competence}

This has to do with the language user's knowledge of the world, his factual knowledge and general world-view. In order to develop the learners at this competence level, the following questions could be given to them after reading a passage.

(1) How far have the social thematic forecasts of the author in the passage manifested in Nigeria?

(2) Which point of view of the author in this story, has become an international working policy? Describe five countries it has so internationally affected?

\section{Conclusion}

Effective teaching is necessary if desired goals will be achieved. Pragmatic approach to language teaching involves the use of activities that will make learning interesting to learners and also enhance their competence and performance in the language. This study has diagnosed some language difficulties that confront language learners and also designed suitable functional and skill-oriented activities that can help in the development of learners' language competence. It is therefore recommended that learners should be made to participate in oral discussions during language teaching. The findings of this study show that most of the students observed were lacking in some skills related to pragmatic use of the English language. The only way to help them develop such skills is to make the teaching of English more practical and activity-oriented so as to involve the learners in language-use right from the classroom. We also suggest that for these activities to be workable and effective, the number of students in the classrooms should be reduced. The ideal teacher-students ratio for a language class should be implemented in schools.

\section{References}

Adegbija, E. E. (1982). A speech act analysis of consumer advertisements. University Microfilms No. 8307973 in Indiana University Ph.D. Dissertation.

Aliyu, J. S. (2001). Mass failure in WAEC-conducted senior secondary English examination in Nigeria: Grammar as road block to candidates' success. Zaria: Tamaza publishing Company Ltd.

Aliyu, J. S. (2006). Upgrading English achievement. Zaria: Tamaza publishing Company Ltd. Bachman, L. (1990). Fundamental considerations in language testing. London: Oxford University Press.

Blakemore, D. (1992). Understanding utterances: An introduction to pragmatics. Oxford: Basil Blackwell. 
Fulcher, G. (2000). The Communicative Legacy in Language Testing. System, 28, 483-497. http://dx.doi.org/10.1177/026553229601300103

Hudson, T. (2001). Indicators for pragmatic instruction some quantitative tools. In K. Rose, \& G. Kasper (Eds.), Pragmatics in language teaching. Cambridge: University Press.

Kasper, G. (2001). Classroom research on inter language pragmatics. In K. Rose, \& G. Kasper (Eds.), Pragmatics in language teaching. Cambridge University Press.

Lawal, A. (1995). Aspects of pragmatic theory. Unpublished Paper, Institute of Education, University of Ilorin, Ilorin.

Lawal, R. A., Ajayi, B. and Raji, W. (1996). A Pragmatic Study of Selected Pairs of Yoruba Proverbs. Journal of Pragmatics, 27, 635-652.

Levinson, S. C. (1980). Speech act theory: The state of the art. Cambridge: Cambridge University Press.

Nunan, D. (1989). Designing tasks for the communicative classroom. Cambridge: Cambridge University Press.

Quasha, S. E. (2003). Testing Communicative Competence Using Mobile Phone Digital Photos. Proceedings of the $2^{\text {nd }}$ Annual Pan-SIG Conference. Japan.

Thomas, J. (1995). Meaning in interaction: An introduction to pragmatics. England: Longman.

Traugott, E., \& Pratt, M. (1980). Linguistics for students of Literature. New York: Harcourt Brace Jovanovich Press.

Winner, M. (2002). Assessment of Social Skills for Students with Asper Syndrome and High-functioning Autism. Assessment for Effective Intervention, 27, 73-80. http://dx.doi.org/10.1177/073724770202700110

\section{Copyright Disclaimer}

Copyright for this article is retained by the author(s), with first publication rights granted to the journal.

This is an open-access article distributed under the terms and conditions of the Creative Commons Attribution license (http://creativecommons.org/licenses/by/3.0/). 